\title{
Application of response surface methodology (RSM) in statistical optimization and pharmaceutical characterization of a patient compliance effervescent tablet formulation of an antiepileptic drug levetiracetam
}

\author{
Abikesh Prasada Kumar Mahapatra ${ }^{1 *}$ (D), Rohit Saraswat ${ }^{1}$, Mahesh Botre $^{2}, 2$ Basudev Paul ${ }^{1}$ and Neelkant Prasad ${ }^{3}$
}

\begin{abstract}
Background: The main objective of the present study was to develop and optimize an effervescent tablet of levetiracetam, an antiepileptic drug, using central composite design with response surface methodology (RSM).The present investigation helps to overcome the problem associated with levetiracetam tablets and liquid dosage forms with children and elderly people like bad taste and swallowing difficulties. It also facilitates as an alternative manufacturing process for advanced patented technology like 3D printing process employed in SPRITAM ${ }^{\circledR}$ tablet. Levetiracetam effervescent tablets were prepared by dry granulation (roll compaction) method using water-soluble excipients and optimized by central composite rotatable design (CCRD) using two variables (citric acid and effersoda) at two levels (high and low). Overall, fourteen formulation trials were generated through statistical software Minitab 17.3.0 placing 6 center points, 4 cube points, and 4 axial points. All formulations were subjected to compression using single punch machine.

Results: Quality attributes of compressed tablets were evaluated using various compendial and non-compendial tests. RSM was used to observe the responses like effervescent time, hardness, and friability of the prepared tablet batches for different levels of all the variables. Polynomial equations were developed, and model plots (contour plot and 3-dimensional model surface plots) were generated to study the impact of acid-base couple on the responses. Finally, the optimized formulation was selected on the basis of desired effervescent time, hardness, friability, percent drug release, and drug content. From the studied RSM design, it was observed that small changes in the independent variables (citric acid and effersoda) correlate with shifts in the dependent variables, i.e., the desired responses. The study reveals that all the independent variables (citric acid and effersoda) and dependent variables (effervescent time, hardness, and friability) have a good correlation as indicated by good linear regression coefficient of $0.9808,0.9939$, and 0.9892 for effervescent time, hardness, and friability respectively.

\footnotetext{
* Correspondence: abikeshmahapatra@gmail.com

${ }^{1}$ School of Pharmacy, OPJS University, Churu, Rajasthan 331303, India

Full list of author information is available at the end of the article
}

\section{Springer Open}

( ) The Author(s). 2020 Open Access This article is licensed under a Creative Commons Attribution 4.0 International License, which permits use, sharing, adaptation, distribution and reproduction in any medium or format, as long as you give appropriate credit to the original author(s) and the source, provide a link to the Creative Commons licence, and indicate if changes were made. The images or other third party material in this article are included in the article's Creative Commons licence, unless indicated otherwise in a credit line to the material. If material is not included in the article's Creative Commons licence and your intended use is not permitted by statutory regulation or exceeds the permitted use, you will need to obtain permission directly from the copyright holder. To view a copy of this licence, visit http://creativecommons.org/licenses/by/4.0/. 


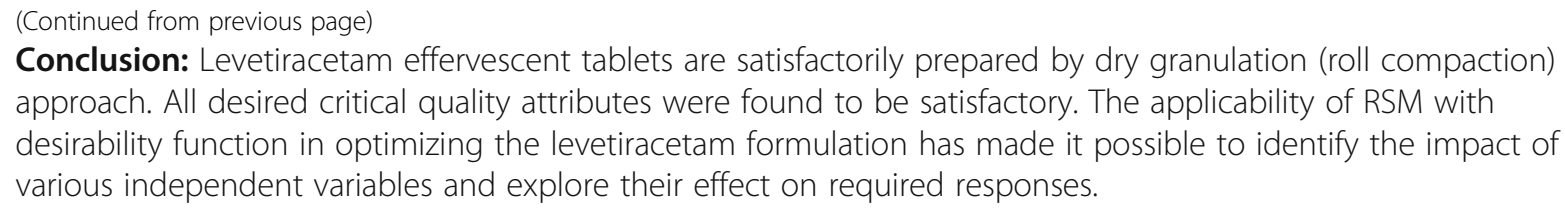

Keywords: Levetiracetam, Effervescent tablet, Water-soluble excipients, Dry granulation, Central composite design, RSM

\section{Background}

Pharmaceutical tablets are still the most accepted and dominant dosage form for drug delivery, occupying twothirds of the global market. Various strategies have been used for manufacturing of tablets including wet granulation, dry granulation, and direct compression. From all these three manufacturing process, dry granulation is the most preferred manufacturing process for moistureand heat-sensitive drug molecules. Roller compaction is the perfect technique for dry granulation in the pharmaceutical industry. The compaction process involves compaction of powder blend followed by compression in a tablet press [1].

In global pharmaceutical market, various grades of excipients are available with unique physico-chemical properties. Selecting suitable excipients for tablet manufacturing is always a crucial process. Proper selection of excipients and their level would deliver cost-effective and reproducible product [2]. Nowadays statistics is an integral part of any research. Thus, efforts have been made to use several statistical designs for development and optimization of different pharmaceutical products. The most commonly used statistical designs in the pharmaceutical development are response surface model [3], factorial design (full or partial) [4], and Taguchi orthogonal array design [5].

Response surface design (RSD) is the most common advanced design used for statistical process control and design of pharmaceutical formulations. It enables the user to develop, improve, and optimize the process parameters by controlling the required responses. Screening of factors is always an important task while implementing any statistical designs. Most commonly, the factors are identified or screened by screening designs like Plackett-Burman or factorial design. RSD, particularly, is selected when we have the important factors in our hand that are affecting our response or when we are expecting curvature in our response.

There are two types of response surface design available, i.e., central composite design (CCD) and BoxBehnken design [6]. The central composite design was used when a sequential experimentation is required whereas Box-Behnken design was used when there is a requirement of fewer design points.
CCD is the most pertinent design with RSM that basically involves cube points, center points, and axial points. Such variety of points arranged the experiments in a block arrangement $[7,8]$. The blocks formed by the central composite design may be orthogonal or rotational. The orthogonal block, created by the central composite design, analyzes the required variables independently and minimizes the variation of regression coefficient, whereas the rotational block provides constant prediction of the variance of all points that are situated at equal distance from the center point $[9,10]$. RSM was first researched by Box and Hunter $[10,11]$ and comprised of statistical models with full polynomial or quadratic relation with the studied variable and response [12-14].

There are several diseases exist that affect the nervous system. Epilepsy, a neurological condition, has become one of the most affected serious and chronic noncommunicable disease condition of the brain with 50 million people affected worldwide. In global market, various anti-epileptic medications are available. Levetiracetam is an antiepileptic drug and acts as presynaptic calcium channel inhibitor. It is used as a monotherapy treatment for partial, monoclonic, and tonic-clonic seizure. It has been used orally as a tablet and solution dosage forms $[15,16]$.

After oral administration, levetiracetam generally takes $1 \mathrm{~h}$ for onset of action. The reported oral bioavailability of levetiracetam has been observed more than $95 \%$. This is due to its rapid absorption after oral administration [17]. Most of the available tablets and other oral dosage forms of levetiracetam are bioequivalent due to its high bioavailability [18].

Levetiracetam has been available in the market as film-coated tablets as well as oral solution. Its tablets are available in 250, 500, 750, and $1000 \mathrm{mg}$ strength in the market. Due to high drug content, the tablets are apparently bigger in size which creates problem during swallowing. The problem associated due to bigger size of the tablet is quite significant to children, elderly people, and handicapped patients [19]. The alternative of administration of this medication is that the tablets may be crushed and placed in food or down a nasogastric tube for those unable to swallow whole tablets. If this is done, it leads 
to bitter taste resulting from exposing the drug powder [20]. Another option for administration of levetiracetam is oral solution dosage form. However, the solution dosage form is not usually preferred due to its short shelf life, unpleasant taste, and uncontrolled dose intake. Thus, there is a requirement of user friendly, patient acceptable, long shelf life, and fast release levetiracetam formulation.

However, SPRITAM ${ }^{\circ}$ is available in the market as tablet for suspension system. SPRITAM ${ }^{\circ}$ is intended to disintegrate in the mouth when taken with a sip of liquid. It utilizes a patented new technology called as 3D printing process to produce solid oral quickly dispersible porous tablets. The most important consideration of this technology is that it produces very porous structure of prepared tablets that enables it to quickly disintegrate or disperse in the mouth immediately with a sip of water. However, the most disadvantage of this technology is that it is not feasible for all pharmaceutical manufacturing units as the process was patented, complicated, and not cost-effective. Thus, there is requirement of alternative manufacturing process or technology of 3D printing process which is easy to manufacture, cost-effective, and economic.

Effervescent tablet dosage form has been paid attention as an alternative dosage form for conventional tablet dosage form especially for pediatric and geriatric patients. The advantages of effervescent formulation suggested ease of use, non-invasive administration, ease of self-medication, and improved patient compliance by use of suitable sweetener and flavor. The idea of effervescent formulation came from the need of a suitable dosage form which helps the children and the elderly patient for administration.

In this study, we attempt to develop effervescent tablets of levetiracetam using water-soluble excipients. The present work holds the advantage of both tablet and liquid dosage form and also helps to overcome the problem encountered in oral tablet and liquid dosage forms. The present study can also be used as an alternative manufacturing process of $3 \mathrm{D}$ printing process employed in SPRITAM $^{\circ}$ tablet. In the present investigation, RSM was utilized to design and optimize the effervescent formulation of levetiracetam, and the effects of "acid: base" couple was accessed on effervescent time, friability, and hardness.

\section{Methods}

\section{Materials}

Levetiracetam $\left(\mathrm{C}_{8} \mathrm{H}_{14} \mathrm{~N}_{2} \mathrm{O}_{2}\right)$ was gifted by VerGo Pharmaceuticals Pvt Ltd.; anhydrous lactose (Domo Ltd.), mannitol (Roquette Feres, France), sorbitol (Roquette Feres, France), citric acid (Merck Ltd., USA), effersoda (SPI Pharma, USA), aspartame (Nutra Sweet, India), orange flavor (Firminch, USA), sodium benzoate (Mallinckrodt Baker, USA), and sodium acetate (Merck Ltd, USA) were procured from the commercial market.

\section{Experimental design of levetiracetam effervescent tablets using CCRD}

CCRD was used for the development and optimization of immediate effervescent levetiracetam tablets using software Minitab 173.0. Two factors having five levels (0, \pm 1 , and $\pm \alpha$ ) of formulation variables were used, designated as X1: citric acid (320-960 mg) and X2: effersoda (320-960 mg), keeping all other excipients and drug constant. RSM was used to evaluate the influence of independent variables (i.e., the factors) on dependent variables (i.e., response) variables of Y1 (hardness), Y2 (friability), and Y3 (effervescent time). The model was further investigated through the multiple linear regression analysis (MLRA), analysis of variance, and percent coefficient variance. A total of 14 experimental runs were generated having 6 center points, 4 cube points, and 4 axial points. The different levels of variables are given in Table 1.The coded and uncoded factors of experimental design are presented in Table 2. For each batch of formulation, drug and other ingredients were accurately weighed (Table 3) using digital balance LC/ GC (AXIS) and sifted through sieve \#40 and \#60. The prepared lubricated blends were compacted by using roll compactor made up from Kevin Mini roller compactor. The compacts were then crushed using an oscillating granulator mill fitted with $1-\mathrm{mm}$ screen and sifted through sieve no. \#60 to get appropriate sized granules. The prepared blends were mixed with extra granular material such as mannitol, sorbitol, orange flavor, aspartame, and colloidal silicon dioxide, and finally lubricated with sodium acetate and sodium benzoate. The prepared final blends of each trial subjected for compression using single punch machine (17 stations, double rotary tablet compression machine (Cadmack, CMB4-MT)). All operations were carried out at lower humidity condition, i.e., at less than $30 \% \mathrm{RH}$ to avoid moisture uptake of excipients from the atmosphere.

\section{Compatibility studies using Fourier transform infrared (FTIR) spectroscopy}

The pure drug levetiracetam and its effervescent formulation were examined for compatibility study employing

Table 1 Levels of variables for optimization

\begin{tabular}{lllllll}
\hline Code & Variables & \multicolumn{6}{l}{ Level of variables } \\
\cline { 3 - 7 } & & $\mathbf{- 1}$ & $\mathbf{0}$ & $\mathbf{+ 1}$ & $\mathbf{- a}$ & $+\mathbf{a}$ \\
\hline X1 & Citric acid & 320 & 640 & 960 & 187.45 & 1092.55 \\
X2 & Effersoda & 320 & 640 & 960 & 187.45 & 1092.55 \\
\hline
\end{tabular}


Table 2 Central composite design by statistical software minitab 17.3.0

\begin{tabular}{llllll}
\hline $\begin{array}{lllll}\text { Run } \\
\text { order }\end{array}$ & \multicolumn{2}{l}{ Citric acid $(\mathbf{m g})$} & & \multicolumn{2}{l}{ Effersoda $(\mathrm{mg})$} \\
\cline { 2 - 3 } \cline { 5 - 6 } \cline { 5 - 6 } & Coded value & Actual value & & Coded value & Actual value \\
\hline 1 & 0.0000 & 640.00 & -1.41421 & 187.45 \\
3 & +1.41421 & 1092.55 & & 0.0000 & 640.00 \\
3 & 0.0000 & 640.00 & & 0.0000 & 640.00 \\
4 & 0.0000 & 640.00 & & 0.0000 & 640.00 \\
5 & 0.0000 & 640.00 & & +1.41421 & 1092.55 \\
6 & 0.0000 & 640.00 & & 0.0000 & 640.00 \\
7 & -1.41421 & 187.45 & & 0.0000 & 640.00 \\
8 & 0.0000 & 640.00 & & 0.0000 & 640.00 \\
9 & 0.0000 & 640.00 & 0.0000 & 640.00 \\
10 & +1.0000 & 960.00 & +1.0000 & 960.00 \\
11 & -1.0000 & 320.00 & -1.0000 & 320.00 \\
12 & -1.0000 & 320.00 & +1.0000 & 960.00 \\
13 & 0.0000 & 640.00 & 0.0000 & 640.00 \\
14 & +1.0000 & 960.00 & -1.0000 & 320.00 \\
\hline
\end{tabular}

FTIR (Shimazu Ltd., Japan) spectroscopy. All samples were powdered properly and mixed with potassium bromide, in a ratio of 1:5 (sample:potassium bromide) under infrared light network. The potassium bromide disks were prepared by compacting the powders with a pressure of $5 \mathrm{t}$ for $5 \mathrm{~min}$. The prepared samples were scanned at a range of 4000 to $400 \mathrm{~cm}^{-1}$ with the resolution of $4 \mathrm{~cm}^{-} 1[21]$.

\section{Evaluation of blend for pre-compression parameters}

The blend was characterized for certain precompression parameters like bulk density, tapped density, Carr's compressibility index, Hausner's ratio, and angle of repose [21-24]. The percentage moisture content present in the blend was determined by using sartorius moisture analyzer. For measurement of loss on drying, about $1 \mathrm{~g}$ of sample was placed in a pan and heated up to $10 \mathrm{~min}$ at $105^{\circ} \mathrm{C}$ temperature.

\section{Evaluation of tablets for post compression parameters}

Evaluation of quality attributes are of prime importance for any pharmaceutical formulation. The critical quality attributes of tablets were evaluated by using different pharmacopeial and non-pharmacopeial tests. The effervescent levetiracetam tablet formulations were evaluated for various quality control tests such as weight variation, hardness, friability, disintegration, and drug content as per the respective standard procedures. Weight variation was performed by randomly selected ten tablets individually from the running batch, hardness was determined by taking twenty tablets from each formulation using Schleuniger hardness tester (Schleuniger \& Co., Switzerland), friability of the tablets was evaluated over $6.5 \mathrm{~g}$ of sample at $25 \mathrm{rpm}$ for $4 \mathrm{~min}$ using Roche friabilator (Electro lab) [25-27]. The effervescent time was

Table 3 Composition of levetiracetam effervescent tablets $500 \mathrm{mg}$

\begin{tabular}{|c|c|c|c|c|c|c|c|c|c|c|c|c|c|c|}
\hline & C1 & $\mathrm{C} 2$ & $\mathrm{C} 3$ & $\mathrm{C} 4$ & C5 & $\mathrm{C} 6$ & C7 & $\mathrm{C8}$ & C9 & C10 & C11 & C12 & C13 & $\mathrm{C14}$ \\
\hline \multicolumn{15}{|l|}{ Intragranular (for compaction) } \\
\hline Levetiracetam & 500 & 500 & 500 & 500 & 500 & 500 & 500 & 500 & 500 & 500 & 500 & 500 & 500 & 500 \\
\hline Anhydrous lactose (lactose 21AN) & 700 & 700 & 700 & 700 & 700 & 700 & 700 & 700 & 700 & 700 & 700 & 700 & 700 & 700 \\
\hline Colloidal silicon dioxide & 16 & 16 & 16 & 16 & 16 & 16 & 16 & 16 & 16 & 16 & 16 & 16 & 16 & 16 \\
\hline Sodium benzoate & 16 & 16 & 16 & 16 & 16 & 16 & 16 & 16 & 16 & 16 & 16 & 16 & 16 & 16 \\
\hline Sodium acetate & 16 & 16 & 16 & 16 & 16 & 16 & 16 & 16 & 16 & 16 & 16 & 16 & 16 & 16 \\
\hline \multicolumn{15}{|l|}{ Extra granular } \\
\hline Mannitol (Pearlitol 200 SD) & 286 & 286 & 286 & 286 & 286 & 286 & 286 & 286 & 286 & 286 & 286 & 286 & 286 & 286 \\
\hline Sorbitol (Neosorb ${ }^{\circledR}$ XTAB 300S ) & 220 & 220 & 220 & 220 & 220 & 220 & 220 & 220 & 220 & 220 & 220 & 220 & 220 & 220 \\
\hline Citric acid & 640 & 1092.55 & 640 & 640 & 640 & 640 & 187.45 & 640 & 640 & 960 & 320 & 320 & 640 & 960 \\
\hline Effersoda & 187.45 & 640 & 640 & 640 & 1092.55 & 640 & 640 & 640 & 640 & 960 & 320 & 960 & 640 & 320 \\
\hline Aspartame & 60 & 60 & 60 & 60 & 60 & 60 & 60 & 60 & 60 & 60 & 60 & 60 & 60 & 60 \\
\hline Orange flavor & 26 & 26 & 26 & 26 & 26 & 26 & 26 & 26 & 26 & 26 & 26 & 26 & 26 & 26 \\
\hline Colloidal silicon dioxide & 16 & 16 & 16 & 16 & 16 & 16 & 16 & 16 & 16 & 16 & 16 & 16 & 16 & 16 \\
\hline Sodium benzoate & 32 & 32 & 32 & 32 & 32 & 32 & 32 & 32 & 32 & 32 & 32 & 32 & 32 & 32 \\
\hline Sodium acetate & 32 & 32 & 32 & 32 & 32 & 32 & 32 & 32 & 32 & 32 & 32 & 32 & 32 & 32 \\
\hline Total (mg) & 2747.45 & 3652.55 & 3200 & 3200 & 3652.55 & 3200 & 2747.45 & 3200 & 3200 & 3840 & 2560 & 3200 & 3200 & 3200 \\
\hline
\end{tabular}


measured by placing an effervescent tablet in a standard volume of water (approx. 120 to $180 \mathrm{ml}$ ) at room temperature and recording the moment when the solution became completely transparent [21, 28]. Drug content analysis was measured by randomly taking ten tablets and crushed in mortar and pestle. Powder content equivalent to weight of one tablet was taken in a $50-\mathrm{ml}$ volumetric flask, extracted with phosphate buffer $\mathrm{pH}$ 6.8. The mixture was filtered with Whatman filter paper, suitably diluted, and drug content was measured using UV spectrophotometer (UV-1800 Shimadzu Corporation Kyoto, Japan) at $\lambda \max 205 \mathrm{~nm}$ [29-31].

\section{Amount of carbon dioxide content [32, 33]}

In a beaker, $10 \%$ sulfuric acid (equivalent to $1 \mathrm{~N}$ ) solution was prepared by taking $6.9 \mathrm{ml}$ of concentrated sulfuric acid in $250 \mathrm{ml}$ of distilled water. One effervescent tablet was placed in $100 \mathrm{ml}$ of prepared sulfuric acid solution. The weight changes were measured, and amount of carbon dioxide generated was determined from the observed weight difference of the sample at the end of effervescence.

\section{In vitro dissolution study [31, 34, 35]}

The dissolution test of the prepared levetiracetam effervescent tablets was performed in phosphate buffer $\mathrm{pH}$ $6.8 \pm 0.1$ as dissolution medium maintained at a temperature of $37 \pm 0.5^{\circ} \mathrm{C}$ at $50 \mathrm{rpm}$ using the USP dissolution rate test apparatus type II (paddle type). A sample of $5 \mathrm{ml}$ was withdrawn every $5 \mathrm{~min}$ interval up to 30 min replenishing with $5 \mathrm{ml}$ to maintain the constant volume after each withdrawal of sample. The sample was filtered through Whatman filter paper (0.45 micron), and then the absorbance of the sample was measured at $205 \mathrm{~nm}$ using a spectrophotometer (UV-1800 Shimadzu Corporation Kyoto, Japan). The amount of drug released was calculated from a previously prepared calibration curve of levetiracetam using phosphate buffer $\mathrm{pH} 6.8 \pm$ 0.1 as a blank. The absorbance was measured at wavelength $205 \mathrm{~nm}$ as levetiracetam is showing maximum absorbance at this wavelength. As the selected wavelength near to UV-visible range, it was further verified. For verification, placebo blend (blend having all excipients and without API) was taken, and absorbance was measured at wavelength $205 \mathrm{~nm}$. It was seen that no interference of placebo blend was observed. Thus, this wavelength was further taken into consideration for dissolution and drug content measurement.

\section{Results}

In the present study, levetiracetam effervescent tablets were prepared using water-soluble excipients. The product development was carried out by using levetiracetam as an API, anhydrous lactose as a diluent, sorbitol as natural sweetener as well as diluent to enhance compressibility, mannitol as a sweetener for creamy texture as well as to enhance binding capacity, aspartame again as a sweetener, orange flavor as a flavoring agent, colloidal silicon dioxide as glidant, citric acid as acidic agent, effersoda as an alkali agent, and sodium acetate and sodium benzoate as lubricants.

The coded and uncoded levels of variables for combinations generated by the minitab software 17.3.0 are shown in Tables 1 and 2. The final compositions of all the executed trials are given in Table 3.

\section{Compatibility studies using FTIR}

The FTIR spectrum of levetiracetam showed various characteristic bands, such as $-\mathrm{NH}$ stretching (amine) at $3360 \mathrm{~cm}^{-1},-\mathrm{C}=\mathrm{C}$ stretching (aromatic) at $2991.59 \mathrm{~cm}^{-1}$, $-\mathrm{C}=\mathrm{O}$ (carboxylic acid) at $1672.28 \mathrm{~cm}^{-1}$, and $-\mathrm{CH}$ stretching (alkyl) at $2939.99 \mathrm{~cm}^{-1}$ (Fig. 1a). The FTIR spectrum of the physical mixture of the levetiracetam and studied excipients has shown all the characteristic bands of levetiracetam that indicate the compatibility between levetiracetam and the studied excipients (Fig. 1b).

\section{Evaluation of blend properties}

The micromeritic parameters for all the formulation blends were performed, and the results are depicted in Table 4. The angle of repose (35.24-45.04 $\left.{ }^{\circ}\right)$, Hausner's ratio (1.23-1.37), and Carr's index (18.52-26.76) were found to be within the specified limits.

\section{Evaluation of post-compression parameters}

All the formulations were subjected to compression after preformulation studies. The compressed tablets were evaluated for different quality control parameters and are presented in Table 5. The results have shown that the different tests such as weight variation, hardness, friability, effervescent time, amount of carbon dioxide content, drug content, and in vitro drug release were within acceptable limits.

\section{Experimental design}

In the present investigation, RSM was selected for optimization. The details of the dependent and independent factors are presented in Tables 1 and 2 . As per the RSM, 14 formulations were formulated and evaluated for their response variables, i.e., hardness, friability, and effervescent time. Quadratic models were applied to study the relationships of factors on hardness, friability, and effervescent time. Statistical model summary of response variables are presented in Tables 6, 7, and 8 . The lack of fit test is performed to analyze the variation between the fitted value and the obtained value. The significant of lack of fit and the $R^{2}$ value of the responses were also estimated. 


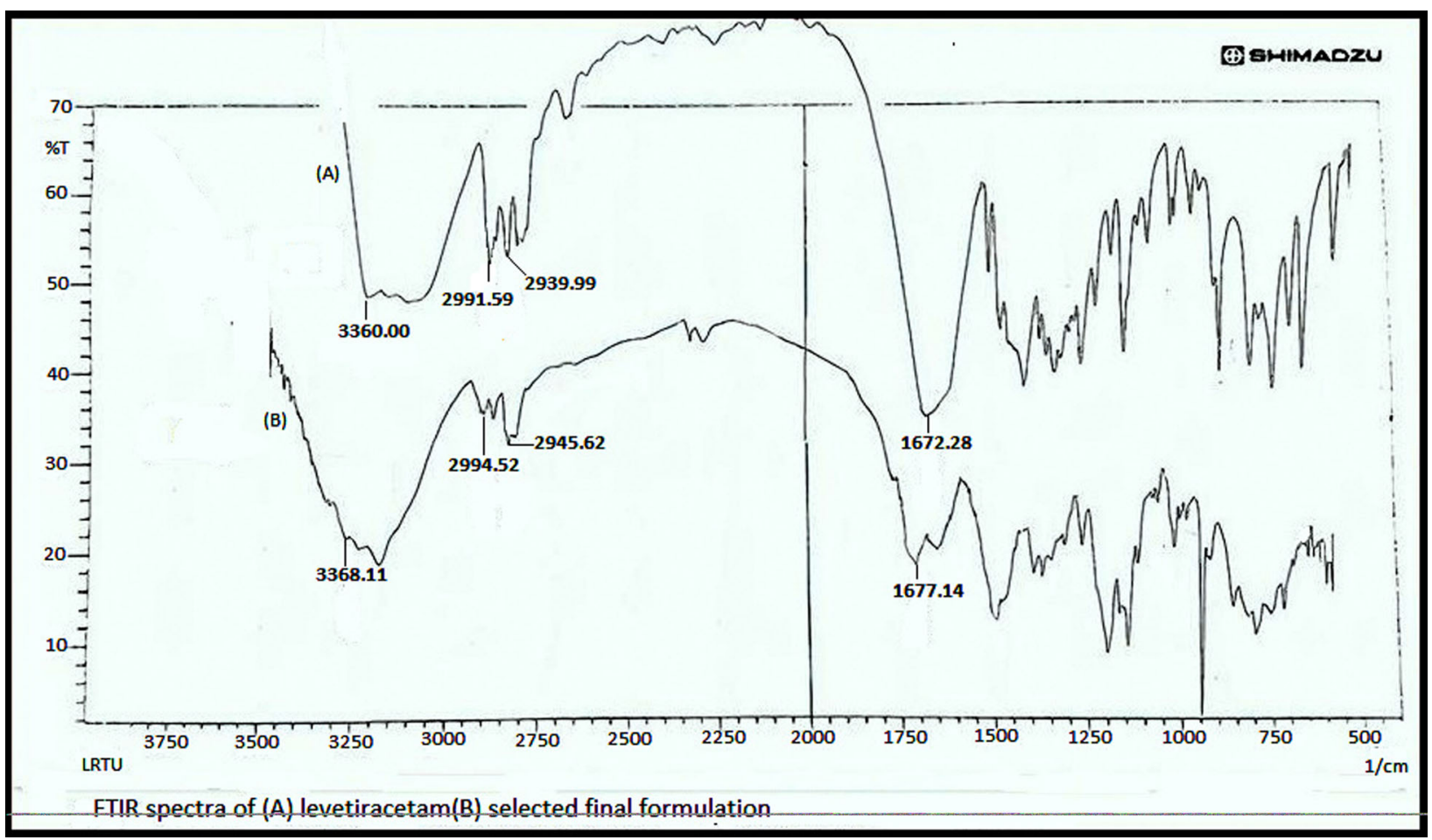

Fig. 1 FTIR spectra of a levetiracetam and $\mathbf{b}$ selected final formulation

RSM effect of citric acid and effersoda on hardness

The result of hardness study is presented in Table 5 . The full quadratic polynomial equation for the measured response (hardness) is given below:

Hardness $(N)=47.04+0.1429$ citric acid $(\mathrm{mg})+$ 0.1995 effersoda -0.000101 citric acid $(\mathrm{mg}){ }^{*}$ citric acid (mg) - 0.000125 effersoda*effersoda -0.000049 citric acid (mg)*effersoda

The above polynomial equation represents the quantitative effect of predictor variables (independent variables) on the measured response hardness. Since the $R^{2}$ of 0.9892 was in close agreement with the adjusted $R^{2}$ of

Table 4 Evaluation of powder blend properties (formulation C1-C14)

\begin{tabular}{lllllll}
\hline Evaluation of powder blend properties & \multicolumn{5}{l}{} \\
\hline Batch code & Bulk density $(\mathbf{g m} / \mathbf{m l})$ & Tap density $(\mathbf{g m} / \mathbf{m l})$ & Carr's index (Cl) & Hausner's ratio & Angle of repose ( $\left.{ }^{\circ}\right)$ & LOD of blend (\%) \\
\hline C1 & 0.61 & 0.75 & 18.52 & 1.23 & 35.24 & $2.19 \pm 0.44$ \\
C2 & 0.53 & 0.69 & 23.47 & 1.31 & 41.25 & $2.22 \pm 0.39$ \\
C3 & 0.60 & 0.75 & 19.41 & 1.24 & 37.21 & $2.13 \pm 0.54$ \\
C4 & 0.58 & 0.73 & 21.05 & 1.27 & 39.41 & $2.25 \pm 0.37$ \\
C5 & 0.52 & 0.68 & 24.05 & 1.32 & 41.32 & $2.33 \pm 0.21$ \\
C6 & 0.61 & 0.76 & 19.59 & 1.24 & 38.22 & $2.18 \pm 0.32$ \\
C7 & 0.60 & 0.76 & 20.47 & 1.26 & 42.22 & $2.36 \pm 0.51$ \\
C8 & 0.59 & 0.74 & 20.08 & 1.25 & 36.21 & $2.44 \pm 0.36$ \\
C9 & 0.58 & 23.82 & 1.31 & 39.39 & $2.06 \pm 0.48$ \\
C10 & 0.51 & 0.76 & 26.76 & 1.37 & 45.04 & $2.33 \pm 0.11$ \\
C11 & 0.63 & 0.69 & 22.84 & 1.30 & 38.83 & $2.28 \pm 0.25$ \\
C12 & 0.59 & 0.81 & 19.35 & 1.24 & 40.22 & $2.05 \pm 0.35$ \\
C13 & 0.60 & 0.73 & 20.29 & 1.25 & 37.54 & $2.31 \pm 0.14$ \\
C14 & 0.58 & 0.75 & 21.05 & 1.27 & 38.61 & $2.13 \pm 0.03$ \\
\hline
\end{tabular}


Table 5 Physicochemical properties of tablets (formulation C1-C14)

\begin{tabular}{llllllll}
\hline Physicochemical properties of tablets & & & & \\
\hline Batch code & Weight variation (mg) & Hardness (N) & Friability (\%) & $\begin{array}{l}\text { Effervescent } \\
\text { time (s) }\end{array}$ & $\begin{array}{l}\text { Amount of carbon } \\
\text { dioxide (g) }\end{array}$ & $\begin{array}{l}\text { Drug content } \\
\text { analysis (\%) }\end{array}$ & $\begin{array}{l}\text { \% drug release } \\
\text { at 5 min }\end{array}$ \\
\hline C1 & $2747.45 \pm 2.9$ & $125 \pm 2.25$ & 0.92 & 68 & $0.11 \pm 0.08$ & 100.8 & $90.2 \pm 0.12$ \\
C2 & $3652.55 \pm 2.5$ & $125 \pm 3.41$ & 0.88 & 80 & $0.17 \pm 0.02$ & 101.4 & $99.9 \pm 0.22$ \\
C3 & $3200 \pm 3.1$ & $153 \pm 3.24$ & 0.43 & 100 & $0.21 \pm 0.06$ & 100.5 & $96.4 \pm 0.74$ \\
C4 & $3200 \pm 3.8$ & $151 \pm 2.22$ & 0.48 & 98 & $0.19 \pm 0.04$ & 99.4 & $98.3 \pm 0.65$ \\
C5 & $3652.55 \pm 2.5$ & $133 \pm 3.54$ & 0.71 & 72 & $0.11 \pm 0.08$ & 96.7 & $96.9 \pm 0.73$ \\
C6 & $3200 \pm 1.0$ & $158 \pm 2.63$ & 0.46 & 96 & $0.10 \pm 0.10$ & 98.4 & $97.7 \pm 0.25$ \\
C7 & $2747.45 \pm 1.7$ & $143 \pm 2.75$ & 0.55 & 83 & $0.21 \pm 1.0$ & 99 & $95.4 \pm 0.44$ \\
C8 & $3200 \pm 2.9$ & $155 \pm 3.08$ & 0.43 & 101 & $0.16 \pm 0.09$ & 98.5 & $99.9 \pm 0.72$ \\
C9 & $3200 \pm 1.7$ & $152 \pm 3.08$ & 0.42 & 102 & $0.19 \pm 1.0$ & 101 & $92.0 \pm 0.33$ \\
C10 & $3840 \pm 3.3$ & $123 \pm 3.77$ & 0.90 & 80 & $0.21 \pm 0.08$ & 102.2 & $95.5 \pm 0.43$ \\
C11 & $2560 \pm 4.2$ & $127 \pm 3.65$ & 0.90 & 70 & $0.17 \pm 0.02$ & 100.6 & $98.9 \pm 0.53$ \\
C12 & $3200 \pm 1.9$ & $142 \pm 2.94$ & 0.49 & 82 & $0.20 \pm 0.04$ & 102.8 & $98.2 \pm 0.22$ \\
C13 & $3200 \pm 1.2$ & $154 \pm 3.57$ & 0.44 & 99 & $0.18 \pm 0.07$ & 99.4 & $97.5 \pm 0.41$ \\
C14 & $3200 \pm 1.0$ & $128 \pm 2.54$ & 0.88 & 81 & $0.17 \pm 0.07$ & 99 & $98.4 \pm 0.36$ \\
\hline
\end{tabular}

0.9683, the above equation showed a good fit to the response variable (hardness). The result of regression analysis for hardness showed a positive sign for citric acid and effersoda. This suggested that with an increase in the amount of citric acid and effersoda concentration, the hardness increases. ANOVA analysis of the model suggested that the independent variables had significantly affected $(p<0.05)$ in predicting the response (hardness), and the coefficient terms with $p$ value less than 0.05 had a significant effect on the prediction efficacy of the model. The discussed relationship of independent variables (citric acid and effersoda) on the response hardness can be easily illustrated from the contour plot and 3D model surface plot of hardness as shown in Figs. 2 and 3.

\section{RSM effect of citric acid and effersoda on friability}

The result of friability study is presented in Table 5 . From the CCD study, it was noted that friability of all formulations were found to be within the acceptable limits of NLT $1 \%$ (0.44 to $0.92 \%)$. The predicted friability values are expressed in the following equation:

Friability $(\%)=2.1726-0.002121$ citric acid $(\mathrm{mg})-$ 0.003349 effersoda +0.000001 citric acid $(\mathrm{mg}){ }^{*}$ citric acid

Table 6 Statistical model summary of citric acid and effersoda on hardness

\begin{tabular}{|c|c|c|c|c|c|c|}
\hline \multirow[t]{2}{*}{ Source of variation } & \multirow[t]{2}{*}{ DF } & \multirow{2}{*}{$\begin{array}{l}\text { Adj sum of } \\
\text { square }\end{array}$} & \multirow{2}{*}{$\begin{array}{l}\text { Adj mean } \\
\text { square }\end{array}$} & \multirow[t]{2}{*}{$F$ value } & \multicolumn{2}{|c|}{$P$ value summary } \\
\hline & & & & & Value & Significant \\
\hline Model & 6 & 2248.22 & 374.70 & 67.26 & 0.000 & Model significant \\
\hline Linear & 2 & 292.84 & 146.42 & 26.28 & 0.001 & \\
\hline Citric acid & 1 & 236.05 & 236.05 & 42.37 & 0.000 & \\
\hline Effersoda & 1 & 56.78 & 56.78 & 10.19 & 0.015 & \\
\hline Square & 2 & 1851.88 & 925.94 & 166.20 & 0.000 & \\
\hline Citric acid $(\mathrm{mg})^{*}$ citric acid $(\mathrm{mg})$ & 1 & 782.17 & 782.17 & 140.40 & 0.000 & \\
\hline Effersoda*effersoda & 1 & 1208.32 & 1208.32 & 216.89 & 0.000 & \\
\hline 2-way interaction & 1 & 100.00 & 100.00 & 17.95 & 0.004 & \\
\hline Citric acid $(\mathrm{mg})^{*}$ effersoda & 1 & 100.00 & 100.00 & 17.95 & 0.004 & \\
\hline Lack-of-fit & 3 & 8.33 & 2.78 & 0.36 & 0.785 & Lack-of-fit not significant \\
\hline \multicolumn{7}{|l|}{ Model summary } \\
\hline S & R-sq & & R-sq (adj) & & R-sq (pred) & \\
\hline 2.36032 & $98.92 \%$ & & $96.83 \%$ & & $94.00 \%$ & \\
\hline
\end{tabular}


Table 7 Statistical model summary of citric acid and effersoda on friability

\begin{tabular}{|c|c|c|c|c|c|c|}
\hline \multirow[t]{2}{*}{ Source of variation } & \multirow[t]{2}{*}{ DF } & \multirow{2}{*}{$\begin{array}{l}\text { Adj Sum of } \\
\text { square }\end{array}$} & \multirow{2}{*}{$\begin{array}{l}\text { Adj Mean } \\
\text { square }\end{array}$} & \multirow[t]{2}{*}{$F$ value } & \multicolumn{2}{|c|}{$P$ value summary } \\
\hline & & & & & Value & Significant \\
\hline Model & 6 & 0.592752 & 0.098792 & 119.27 & 0.000 & Model significant \\
\hline Linear & 2 & 0.150733 & 0.075367 & 90.99 & 0.000 & \\
\hline Citric acid & 1 & 0.091740 & 0.091740 & 110.75 & 0.000 & \\
\hline Effersoda & 1 & 0.058994 & 0.058994 & 71.22 & 0.000 & \\
\hline Square & 2 & 0.395729 & 0.197865 & 238.88 & 0.000 & \\
\hline Citric acid $(m g)^{*}$ citric acid $(\mathrm{mg})$ & 1 & 0.150393 & 0.150393 & 181.56 & 0.000 & \\
\hline Effersoda*effersoda & 1 & 0.274239 & 0.274239 & 331.08 & 0.000 & \\
\hline 2-way interaction & 1 & 0.046225 & 0.046225 & 55.81 & 0.000 & \\
\hline Citric acid $(\mathrm{mg})^{*}$ effersoda & 1 & 0.046225 & 0.046225 & 55.81 & 0.000 & \\
\hline Lack-of-fit & 3 & 0.004332 & 0.001444 & 3.94 & 0.109 & Lack-of-fit not significant \\
\hline \multicolumn{7}{|l|}{ Model summary } \\
\hline$S$ & R-sq & & R-sq (adj) & & R-sq (pred) & \\
\hline 0.0287805 & $99.03 \%$ & & $98.02 \%$ & & $93.92 \%$ & \\
\hline
\end{tabular}

$(\mathrm{mg})+0.000002$ effersoda*effersoda +0.000001 citric acid (mg)*effersoda

The equation clearly indicated that both the factors citric acid and effersoda had a negative sign. Thus, it can be interpreted that both the variables individually have opposing effect. Based on the values and signs of the coefficients, it can be concluded that the concentration of citric acid and effersoda had a negligible effect on friability. ANOVA analysis of the model equation generated suggested that the independent variables had significantly affected $(p<0.05)$ in predicting the response (friability). However, from the contour and 3D surface plot, it can be identified that the required friability was achieved in the range of citric acid:effersoda in 640:640 mg (i.e., 1:1 ratio). The standard error of the regression equation $(S)$ represents how the regression equation fitted the data. The $S$ value represents the relation between actual and predicted response in Table 7.

Contour plot and 3D model surface plot of friability are illustrated in Figs. 4 and 5 respectively.

\section{RSM effect of citric acid and effersoda on effervescent time}

Effervescent time is an important evaluation parameter for any effervescent tablet formulation. Thus, the above study also included effervescent time as a repose parameter. From the study, the predicted effervescent time values are expressed in the following equation:

Table 8 Statistical model summary of citric acid and effersoda on effervescent time

\begin{tabular}{|c|c|c|c|c|c|c|}
\hline \multirow[t]{2}{*}{ Source of variation } & \multirow[t]{2}{*}{ DF } & \multirow{2}{*}{$\begin{array}{l}\text { Adj sum of } \\
\text { square }\end{array}$} & \multirow{2}{*}{$\begin{array}{l}\text { Adj mean } \\
\text { square }\end{array}$} & \multirow[t]{2}{*}{$F$ value } & \multicolumn{2}{|c|}{$P$ value summary } \\
\hline & & & & & Value & Significant \\
\hline Model & 6 & 1945.25 & 324.21 & 59.44 & 0.000 & Model significant \\
\hline Linear & 2 & 37.51 & 18.76 & 3.44 & 0.091 & \\
\hline Citric acid & 1 & 2.83 & 2.83 & 0.52 & 0.495 & \\
\hline Effersoda & 1 & 34.68 & 34.68 & 6.36 & 0.040 & \\
\hline Square & 2 & 1842.35 & 921.17 & 168.89 & 0.000 & \\
\hline Citric acid $(\mathrm{mg})^{*}$ citric acid (mg) & 1 & 507.71 & 507.71 & 93.08 & 0.000 & \\
\hline Effersoda*effersoda & 1 & 1456.01 & 1456.01 & 266.95 & 0.000 & \\
\hline 2-way interaction & 1 & 42.25 & 42.25 & 7.75 & 0.027 & \\
\hline Citric acid $(m g)^{*}$ effersoda & 1 & 42.25 & 42.25 & 7.75 & 0.027 & \\
\hline Lack-of-fit & 3 & 25.51 & 8.50 & 2.69 & 0.182 & Lack-of-fit not significant \\
\hline \multicolumn{7}{|l|}{ Model Summary } \\
\hline S & $\mathrm{R}-\mathrm{sq}$ & & R-sq (adj) & & R-sq (pred) & \\
\hline 2.33544 & $98.08 \%$ & & $96.43 \%$ & & $84.95 \%$ & \\
\hline
\end{tabular}




\section{Contour Plot of Hardness(N) vs Effersoda, Citric acid (mg)}
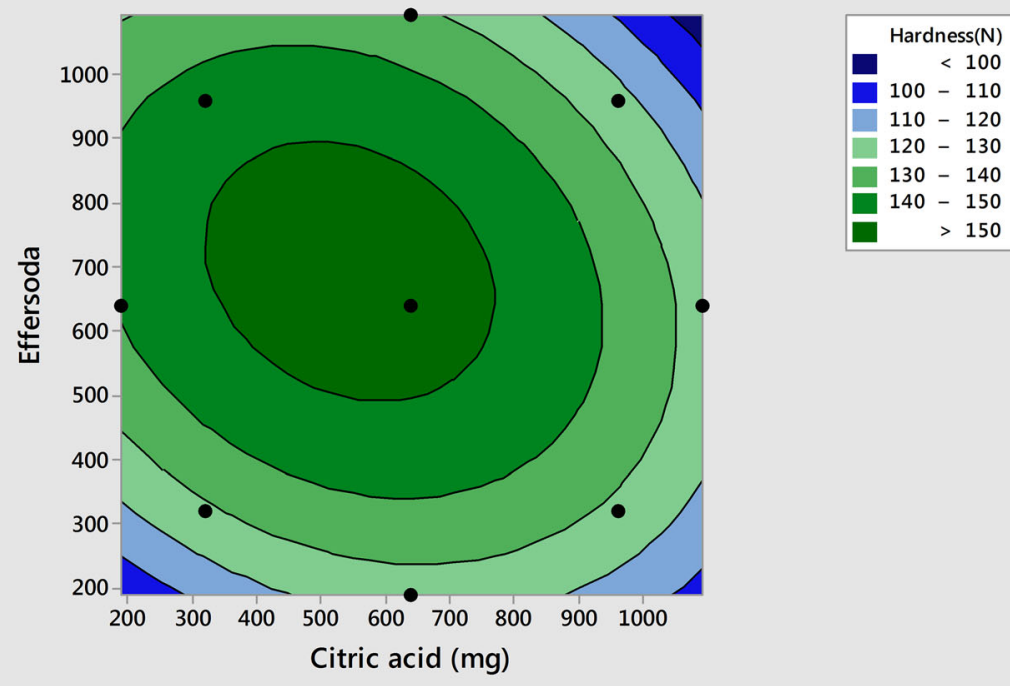

Fig. 2 Contour plot of hardness vs. effersoda and citric acid

Effervescent time $(\mathrm{Sec})=-8.35+0.1258$ citric acid $(\mathrm{mg})+0.2023$ effersoda -0.000081 citric acid $(\mathrm{mg})^{*} \mathrm{ci}-$ tric acid $(\mathrm{mg})-0.000137$ effersoda"effersoda -0.000032 citric acid*effersoda

The equation for effervescent time showed a positive sign for both the factors citric acid and effersoda. ANOVA analysis of the model equation generated suggested that the independent variables had no significant effect on the predicting response (effervescent time) as the linear effect was more than $0.05(p>0.05)$. However, model suggested that the interaction effect (citric acid"effersoda) and squared effect (citric acid"citric acid and effersoda"effersoda) had significantly affected $(p<0.05)$ in predicting the response effervescent time. The model coefficient terms in the polynomial equation model had a significant effect on the prediction efficacy of the model with a $p$ value less than 0.05 . The contour plot of effervescent time also provides a two-dimensional view of the contour lines of constant responses. The surface plot provides a threedimensional view of the relationship between the two

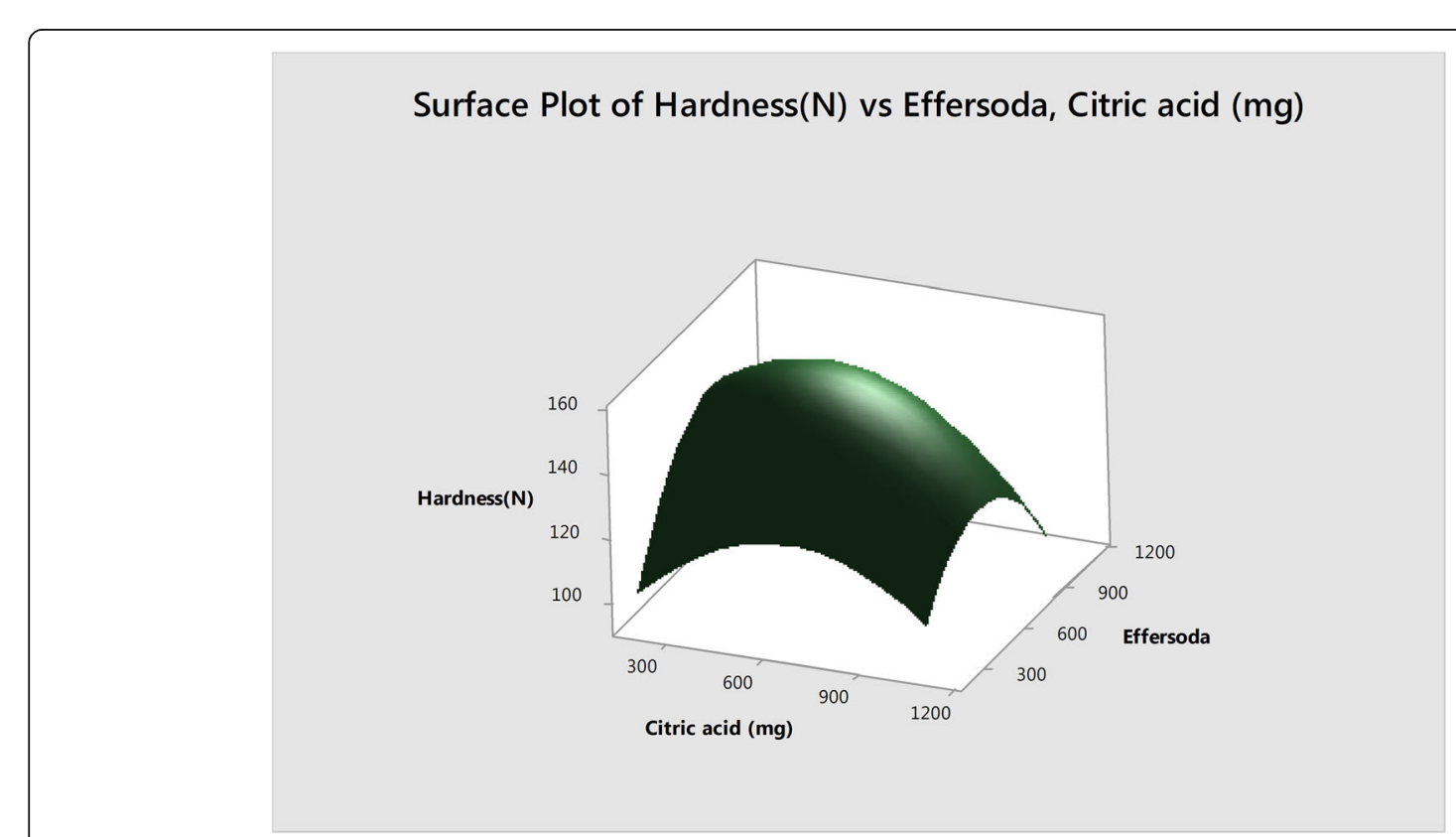

Fig. 3 3D model surface plot of hardness vs. effersoda and citric acid 


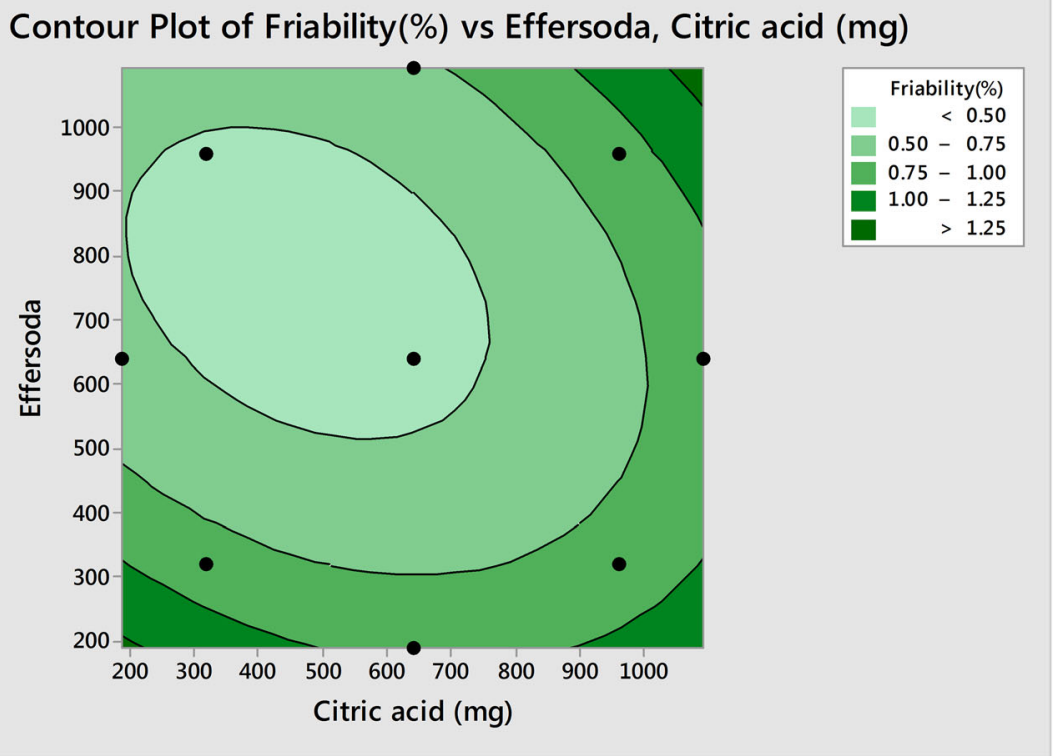

Fig. 4 Contour plot of friability vs. effersoda and citric acid

factors citric acid and effersoda and response effervescent time. The standard error of the regression equation $(S)$ which represents the relation between actual and predicted response is presented Table 8.

The details of the contour plot and 3D model surface plot of effervescent time are shown in Figs. 6 and 7 respectively.

\section{Discussion}

Each of the levetiracetam effervescent tablets consists of a particular composition of citric acid and effersoda. The results of the FTIR study demonstrates that the excipients used in the present study are compatible with levetiracetam and there is no interaction between levetiracetam drug and other ingredients.

It is always critical and tedious to develop and optimize complex manufacturing processes of any dosage form. Thus, efforts have been made to utilize different statistical designs to overcome these types of problems. Among various experimental designs, RSD is the most common advanced design used for statistical process control and

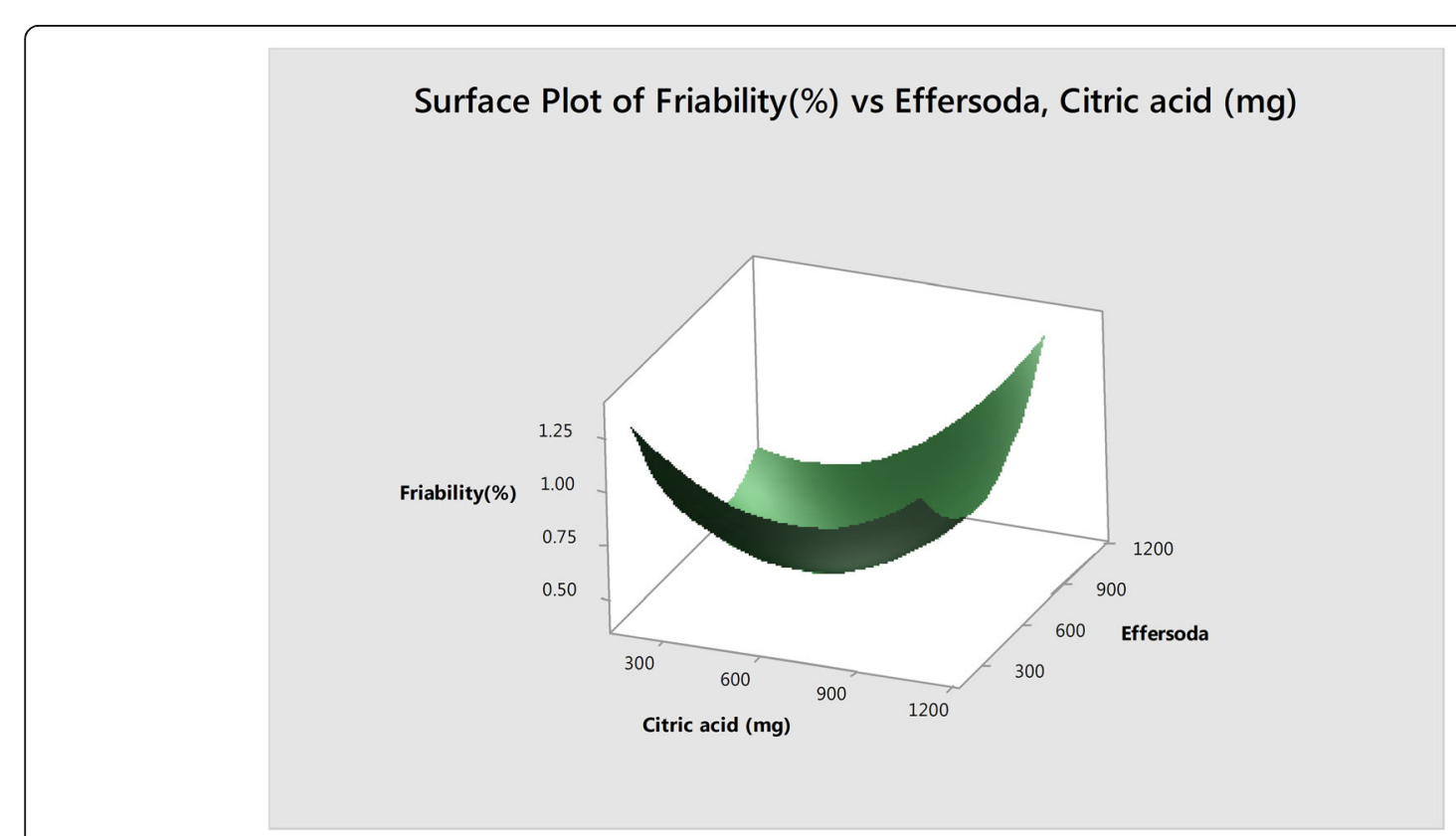

Fig. 5 3D model surface plot of friability vs. effersoda and citric acid 


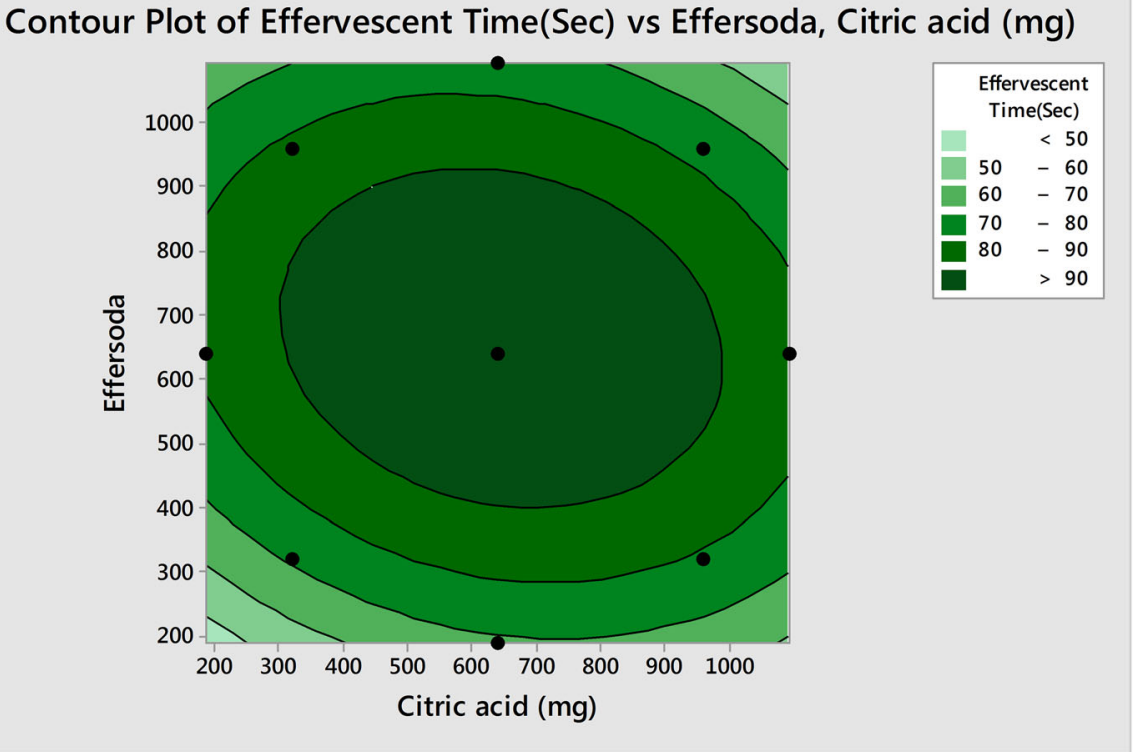

Fig. 6 Contour plot of effervescent time vs. effersoda and citric acid

design of pharmaceutical formulations. Based on selected design, a total of 14 formulation combinations (C1-C14) were made and evaluated for micromeritic properties (angle of repose, bulk density, tapped density, Carr's index, Hausner's ratio, and water content).

From the preformulation study, it was observed that majority of formulations exhibited fair angle of repose, reflecting excellent or good flow abilities as per USP general chapter [21]. However, the compressibility of blends were coming under fair (16-20) to passable (20-25) category. While there were variations in the bulk density of the formulations, the tapped density of all the formulations were found to be close to each other. It has been observed that as the concentration of citric acid and effersoda increased, the flow property decreased. This is due to very poor rheological properties of both citric acid and effersoda [36].

The final lubricated powder blends were used for the development of levetiracetam effervescent tablets. The formulated effervescent tablets were evaluated for

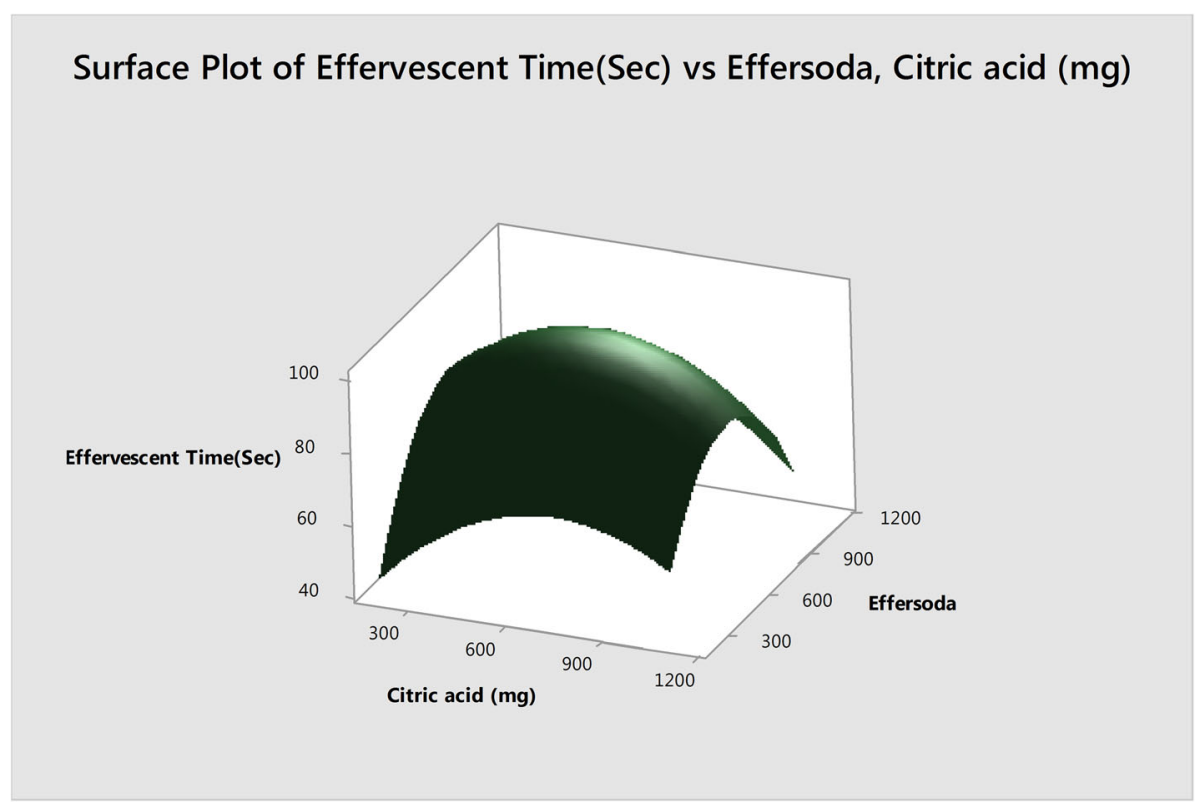

Fig. 7 3D model surface plot of effervescent time vs. effersoda and citric acid 
various parameters, such as weight variations, hardness, friability, effervescent time, amount of carbon dioxide released, drug content analysis, and percentage of drug release.

Weights of tablet layers of all formulations (C1-C14) were in close proximity to the actual value. It has been observed that the percentages of drug release for all formulations were found to be more than $90 \%$. It is due to BCS class I solubility characteristics of levetiracetam which enables higher solubility of levetiracetam across the $\mathrm{pH}$.

The release of carbon dioxide study of the formulations was carried out by using alcalimetric method. In this method, the water is taken by the sulfuric acid and thus, the determination is more accurate and exact [33]. From the study, it has been observed that apparently a lower amount of carbon dioxide is being released for all formulations. This may be due to use of hygroscopic diluents such as sorbitol and anhydrous lactose. The high absorption capacity of these diluents causes beginning of an effervescent reaction slow. A similar type of result was reported in a study while developing the effervescent formulation containing sorbitol as a diluent [37]. It has been also observed that the amount of carbon dioxide released for all formulations were similar and of close proximity to each other.

For the optimization of citric acid and effersoda ratio, the effect of variables on hardness, friability, and effervescent time was investigated through polynomial equation and response curves.

The RSM effect of each response was studied with respect to the independent variable citric acid and effersoda. From the study of RSM effect of citric acid and effersoda on hardness, it has been observed that the hardness vary from 123 to $158 \mathrm{~N}$. The observed tablet hardness was relatively higher. This result is due to the properties of used excipients such as anhydrous lactose, mannitol, and starch. All these excipients are having high-binding capacity, good compressibility which enables to produce quality, robust tablets at lower compression forces. Moreover, anhydrous lactose has a lower lubrication property which enables high elastic modulus and tensile strength. In the formulation, higher amount of anhydrous lactose was used which reduces surface irregularities and increases the tensile strength. A study by Sun et al. also obtained similar results by using lactose and mannitol as a diluent [38].

There was a clear indication from the results that the ratio of citric acid and effersoda imposes a great impact on the response variable hardness. A trend of increase in hardness of the tablet was observed with increase in concentration of citric acid and effersoda ratio from 187.5 to $640 \mathrm{mg}$. The increase in tensile strength of the tablets with increase in concentration of citric acid is attributed due to the physical properties of citric acid. The unique coarser particle size properties of citric acid support the bonding between the particle surfaces and resulted in a stronger compact. As a result with increase in concentration of citric acid:effersoda ratio, the hardness also showed an increasing or upward trend. The results obtained were in consonance with the study conducted by Sun et al. reporting a relation of citric acid with hardness [38].

However, it has been observed that the required hardness was achieved when citric acid:effersoda was used in 640:640 mg (1:1 ratio). Higher amount of both the ingredients decreases the hardness. This could be attributed due to the plasticizer properties of citric acid when used in larger quantity. As the citric acid concentration was increased, the citric acid present in the blend played a role of plasticizer, which decreased the interactions among the macromolecules and resulted in the decrease of the tensile strength [39]. The diminution of hardness may also be endorsed due to the plastic deformation of sodium bicarbonate when compressed. The results obtained were in agreement with the early work with sodium bicarbonate suggesting plastic deformation [40].

From the RSM effect of citric acid and effersoda on friability, it was observed that all formulations were within the friability limit of not more than $1 \%$. A direct relationship between percentage of friability and tablet hardness was observed. Study has also reported that there is a direct relationship that exists between percentages of friability with the tablet hardness [41]. From the analyzed data, it was inferred that friability was less when the concentration of both the variables are in 640 mg:640 mg (1:1 ratio). However, higher friability was observed when the concentrations of both the variables are less than $640 \mathrm{mg}$, and same trend was observed with higher concentration of citric acid and effersoda. The full quadratic polynomial equation model used to measure the response friability revealed very negligible and small values of interaction effects, squared effects, and linear effects. The observed values of MLRA studies indicated that the obtained results of friability are mainly influenced by hardness.

There was a clear indication from the results that there was no significant effect of both the independent factors individually on effervescent time. However, ratio of citric acid and effersoda imposes a great impact on the response variable effervescent time. A trend of decrease in effervescent time was observed with increase in concentration of both citric acid and effersoda from 640 to $1092 \mathrm{mg}$. This may be due to increasing amounts of citric acid and sodium bicarbonate that result in formation of carbon dioxide which helps to break up the tablet and accelerates faster reaction [28].The high hardness of the tablet also affected the effervescent time. In hardness 
study, it was observed that there was an increase in hardness of the tablets with increase in concentration of citric acid and effersoda ratio from 187.5 to $640 \mathrm{mg}$. On the other hand, higher amount of both the ingredients decreases the hardness. The similar trend was observed for effervescent time also. Thus, it was believed that the effervescent time was driven by both hardness and reaction of both citric acid and effersoda. Similar types of results were observed by Sun et al. [38] while developing fast dispersible fruit tablet made from mango, Chlorella, and cactus powder.

The RSM effect of citric acid and effersoda on effervescent time revealed that higher effervescent time was observed with citric acid:effersoda in $640 \mathrm{mg}: 640 \mathrm{mg}$ (1:1 ratio). Our observed effervescent time with citric acid: effersoda in $640 \mathrm{mg}: 640 \mathrm{mg}$ (1:1 ratio) was found to be from 96 to $102 \mathrm{~s}$. A lower effervescent time was reported with other combinations of citric acid and effersoda (68 to $83 \mathrm{~s}$ ). Moreover, as per EP, the limit for effervescent time should be less than $5 \mathrm{~min}$. All the effervescent tablet formulation had acceptable effervescent time value. However, based on the required responses, i.e., hardness, friability, and effervescent time, the formulation containing citric acid:effersoda in $640 \mathrm{mg}: 640 \mathrm{mg}$ (1:1 ratio) was considered as optimized formulation.

The standard error of the regression equation $(S)$ which represents the relation between actual and predicted response was found to be 2.36032, 0.02878, and 2.3554 for hardness, friability, and effervescent time respectively. It represents the average distance of the data points from the fitted line and found to be $2.36 \%, 0.02 \%$, and $2.35 \%$ respectively for hardness, friability, and effervescent time. The adjusted regression values $\left(R^{2}\right)$ for hardness, friability, and effervescent time were 0.9939, 0.9892 , and 0.9808 respectively. The lower $S$ value and higher adjusted regression values $\left(R^{2}\right)$ reflected the appropriateness or goodness of the model. Among all the manufactured formulations, C3, C4, C6, C8, C9, and $\mathrm{C} 13$ were selected as optimized formulations in view of reduced friability, acceptable hardness, and effervescent time. These 6 trials represent the center point of the studied model.

\section{Conclusion}

Optimized formulations of immediate release levetiracetam effervescent tablet with $20 \%$ of citric acid $(640 \mathrm{mg})$ and $20 \%$ effersoda $(640 \mathrm{mg})$ was successfully developed by dry granulation (roll compaction) using water-soluble excipients through CCRD with desired response attributes of effervescent time, hardness, and friability. A quadratic model was used to study the influence of formulation factors on response variables using RSM. Statistical analysis of proposed model showed good coefficient of regression for effervescent time (0.9808), hardness (0.9939), and friability (0.9892). $F$ ratios of the regression for all test variables against response variables were significant. Predicted and actual results are in agreement with 95\% confidence interval. For acceptance of children and elderly people, the bitter taste of the formulation was enhanced by using aspartame and orange flavor in a suitable concentration. The study demonstrated that CCRD with RSM is a systematic optimization approach which could be effectively used to study the inter-relationships of studied variables.

\section{Abbreviations}

RSM: Response surface methodology; RSD: Response surface design; CCRD: Central composite rotatable design; CCD: Central composite design; MLRA: Multiple linear regression analysis; FTIR: Fourier transform infrared spectroscopy; API: Active pharmaceutical ingredients; USP: United State Pharmacopeia; ANOVA: Analysis of variance; NLT: Not less than; R-sq: R square; Adj: Adjusted; Pred: Predicted; DF: Degree of freedom; EP: European Pharmacopoeia; BCS: Biopharmaceutical Classification System

\section{Acknowledgements}

The authors express their sincere thanks to the management of VerGo Pharma Research Pvt Ltd, Goa, India, for providing necessary support to carry out the above research work.

\section{Authors' contributions}

We declare that this work was done by the authors named in this article: APKM conceived and designed the study. APKM and MBB carried out the laboratory work and collected and analyzed the data. MBB and BP drafted the manuscript. DRS supervised the work and assisted in the data analysis. NP contributed to final revision of the manuscript. All authors have read and approved the final manuscript.

\section{Funding}

The authors have no funding to report.

\section{Availability of data and materials}

All necessary data generated or analyzed during this study are included in this published article. Any additional data could be available from the corresponding author upon request.

Ethics approval and consent to participate Not applicable

\section{Consent for publication}

Not applicable

\section{Competing interests}

The authors declare that they have no competing interests

\section{Author details}

${ }^{1}$ School of Pharmacy, OPJS University, Churu, Rajasthan 331303, India. ${ }^{2}$ Tatyasaheb Kore College of Pharmacy, Warananagar, Maharashtra 416113, India. ${ }^{3}$ SGT College of Pharmacy, SGT University, Gurugram, Haryana 122505, India.

Received: 22 April 2020 Accepted: 31 August 2020

Published online: 16 November 2020

\section{References}

1. Zhang Y, Y Law, S Chakrabarti(2003) Physical properties and compact analysis of commonly used direct compression binders. AAPS Pharm. Sci. Tech 4(4):489-499. https://doi.org/10.1208/pt040462

2. Jivraj M, Martini LG, Thomson CM (2000) An overview of the different excipients useful for the direct compression of tablets. PSTT 3(2):58-63 https://doi.org/10.1016/s1461-5347(99)00237-0

3. Pabari RM, Ramtoola Z (2012) Application of face centred central composite design to optimize compression force and tablet diameter for the 
formulation of mechanically strong and fast disintegrating orodispersible tablets. Int. J. Pharm. 430(1-2):18-25. https://doi.org/10.1016/j.ijpharm.2012. 03.021

4. Pani NR, Nath LK, Bhunia B (2010) Formulation, development, and optimization of immediate release nateglinide tablets by factorial design. Drug Discov Ther 4(6):453-458

5. Linden R, Ortega GG, Petrovick PR, Bassani VL (2000) Response surface analysis applied to the preparation of tablets containing a high concentration of vegetable spray-dried extract. Drug Dev Ind. Pharm. 26(4): 441-446. https://doi.org/10.1081/ddc-100101251

6. Late SG, Banga AK (2010) Response surface methodology to optimize novel fast disintegrating tablets using $\beta$ cyclodextrin as diluent. AAPS Pharm. Sci. Tech 11(4):1627-1635. https://doi.org/10.1208/s12249-010-9541-6

7. Muthu AK, Gupta TR, Sharma S, Smith AA, Manavalan R, Kannappan N (2008) Simultaneous estimation of amlodipine and atorvastatin in tablets using orthogonal function ratio spectrometry. Int J ChemSci 6

8. Bezerra MA, Santelli RE, Oliveira EP, Villar LS, LA Escaleira (2008) Response surface methodology (RSM) as a tool for optimization in analytical chemistry. Talanta 76(5):965-977. https://doi.org/10.1016/.talanta.2008.05.019

9. Ghosh S, Rao CR (1996) Response surface designs. Design and analysis of experiment Hand book of Statistics, Vol13. Elsevier Sciences B.V, P 343-375. https://doi.org/10.1016/S0169-7161(96)13013-3

10. Singh B, Chakkal SK, Ahuja N (2006) Formulation and optimization of controlled release mucoadhesive tablets of atenolol using response surface methodology. AAPS Pharm Sci Tech 7(1):E19-E28. https://doi.org/10.1208/pt070103

11. Soares LAL, González-Ortega G, Petro-vick PR, Schmidt PC (2005) Optimization of tablets containing a high dose of spray-dried plant extract: a technical note. AAPS Pharm. Sci. Tech 6(3): E367-371 https://doi.org/10. 1208/pt060346

12. Box GEP, Wilson KB (1951) On the experimental attainment of optimum conditions. Journal of Statistical Royal Society, Vol. 13, Series 1, P 1-45

13. Kassem MA, Shaboury KME, Mohammad Al (2019) Application of central composite design for the development and evaluation of chitosan-based colon targeted microspheres and in vitro characterization. Indian J Pharm Sci 81(2):354-364 https://doi.org/10.36468/pharmaceutical-sciences.517

14. Rabia B, Muhammad HS, Huma A, Farya Z (2014) Formulation design and optimization of aceclofenac tablets (100 mg) using central composite design with response surface methodology. Lat Am J Pharm 33(6):1009-1018

15. Khalil BA (2008) Levetiracetam in the treatment of epilepsy. Neuropsychiatric Disease and Treatment 4(3):507-523 https://doi.org/10, 2147/ndt.s2937

16. ChaninW JD, Diana M, Owais K, Amanda W, Ekokobe F, Darin G, Jose A (2013) Clinical pharmacology and pharmacokinetics of levetiracetam. Front Neurol 4:1-5 https://doi.org/10.3389/fneur.2013.00192

17. Patsalos PN (2004) Clinical pharmacokinetics of levetiracetam. Clin Pharmacokinetics 43(11):707-724 https://doi.org/10.2165/00003088200443110-00002

18. Rodney AR (2001) Pharmacokinetics of levetiracetam. Epilepsia 4(42):24-27 https://doi.org/https://doi.org/10.1046/j.1528-1157.2001.0420s4024.x

19. Mahmut $B$ (2011) Water soluble composition of levetiracetam and use of said composition in the treatment of partial seizures. Patent no WO 2011/ 136751 A2, 3 Nov 2011.

20. Sivaneswari S, Karthikeyan E, Veena, Chandana PJ, Sai SP, Subhashree P, Ramya L, Ashok CK (2016) Physiochemical characterization of taste masking levetiracetam ion exchange resinates in the solid state and formulation of stable liquid suspension for pediatric use. Beni-suef Uni Jr App Sci 5(2):126133 https://doi.org/10.1016/j.bjbas.2016.04.004

21. General chapter (2016) U.S Pharmacopoeia. https://www.usp.org/sites/ default/files/files/usp/document/harmonization/genchapter/g05_pf_30_6_2 004.pdf. Accessed 05 Apr 2020

22. Rakhi BS, Mobin AT, Mansoor AK (2008) Comparative evaluation of flow for pharmaceutical powders and granules. AAPS Pharm Sci Tech 9(1):250-258. https://doi.org/. https://doi.org/10.1208/s12249-008-9046-8

23. Salim PG, Siddaiah M (2018) Formulation and evaluation of effervescent tablets: a review. JDDT. 8(6):296-303 https://doi.org/10.22270/jddt.v8i6.2021

24. Patel NMP (2009) Development of directly compressible co-processed excipient for dispersible tablets using $3^{2}$ full factorial design. Int J Pharm Pharm Sci 1(1):125-148

25. Harish NM, Prabhkar P, Ahmed GM, Yadav B, Narayan CR, Satyanarayana D (2008) Formulation and evaluation of gastric oral floating tablet of glipzide. Indian JPharm Educ Res 42(2):174-183
26. Wells Jl (1998) Pharmaceutical Preformulation. The physicochemical properties of drug substances, Ellis Horwood, Chichester,UK

27. Kaerger JS, Edge S, Price R (2004) Influence of particle size and shape on flowability and compatibility of binary mixtures of paracetamol and microcrystalline cellulose. Eur J Pharm Sci 22(2-3):173-179 https://doi.org/10. 1016/j.ejps.2004.03.005

28. Taymouri S, Mostafavi A, Javanmardi M (2019) Formulation and optimization of effervescent tablet containing bismuth sub-citrate. J Rep Pharm Sci 8:2 https://doi.org/10.4103/jrptps.JRPTPS_11_19

29. Rajalakshmi G, Vamsi C, Balachandar R, Damodharan N (2011) Formulation and evaluation of diclofenac potassium effervescent tablets. Int J Phar Bio Res 2(4):237

30. Zhou Q, Armstrong B, Larson I, Stewart PJ, Morton DA (2010) Improving powder flow properties of a cohesive lactose monohydrate powder by intensive mechanical dry coating. J. Phar. Sci. 99(2): 969-981 https://doi.org/ 10.1002/jps.21885

31. Dissolution database (2020) U.S Food \& Drug Administration https://www. accessdata.fda.gov/scripts/cder/dissolution/dsp_getallData.cfm. Accessed 05 Apr 2020.

32. Singh LP, Rajesh KS, Umalkar DG, Chauhan VK, Rana V, Vasava KS (2011) Floating effervescent tablet: a review. J Pharm Biomed Sci 5(11):1-6

33. Amela J, Salazar R, Cemeli J (1993) Methods for the determination of the carbon dioxide evolved from effervescent systems. Drug Dev Ind Pharm 19(9):1019-1036 https://doi.org/10.3109/03639049309062998

34. Poongothai S, Balaji V, Madhavi B, Reddy AA, llavarasan R, Karrunakaran CM (2011) A sensitive dissolution test method for the development and validation of levetiracetam tablets by reverse phase-HPLC technique. IntJ PharmTech Res 3(2):1023-1032

35. Manuela C, Susan M, Fiorenzo A, Roberto R, Agostino B (2008) Simple and validated HPLC-UV analysis of levetiracetam in deproteinized plasma of patients with epilepsy. J. Chromatogr. B: 873(1):129-132 https://doi.org/10. 1016/j.jchromb.2008.08.007

36. Khan A, lqbal Z, Rehman Z, Nasir F, Khan A, Imal M, Mohammad M (2014) Application of SeDeM Expert system in formulation development of effervescent tablets by direct compression. Saudi Pharmaceutical Journal 5(22):433-444 https://doi.org/10.1016/j.jsps.2013.07.002

37. Aslani A, Fattahi $F$ (2013) Formulation, characterization and physicochemical evaluation of potassium citrate effervescent tablets. Adv Pharm Bul 3(1): 217-225 https://doi.org/10.5681/apb.2013.036

38. Sun $H$, Wang $X$, Wang J, Shi G, Chen $L$ (2019) Influence of the formula on the properties of a fast dispersible fruit tablet made from mango, Chlorella, and cactus powder. Food Sci Nutr 8:479-488 https://doi.org/10.1002/fsn3. 1330

39. Shi R, Bi J, Zhang Z, Zhu A, Chen C, Zhou X, Zhang L, Tian W (2008) The effect of citric acid on the structural properties and cytotoxicity of the polyvinyl alcohol/starch films when molding at high temperature. Carbohydr Polym 74:763-770 https://doi.org/10.1016/j.carbpol.2008.04.045

40. Mattsson S, Nystrom C (2000) Evaluation of strength-enhancing factors of a ductile binder in direct compression of sodium bicarbonate and calcium carbonate powders. Eur J Phar Sc 10:53-66

41. Gordon MS (1994) Process considerations in reducing tablet friability and their effect on in vitro dissolution. Drug Dev Ind Pharm 20:0363-9045

\section{Publisher's Note}

Springer Nature remains neutral with regard to jurisdictional claims in published maps and institutional affiliations. 